\title{
IDENTIFIKASI MORFOLOGI DAN KEKERABATAN SALAK DI JAWA TIMUR
}

\author{
${ }^{1}$ Chitra Dewi Yulia Christie, ${ }^{2}$ Nia Agus Lestari \\ ${ }^{1,2}$ Fakultas Pertanian, Universitas Kahuripan Kediri \\ ${ }^{1,2}$ Kediri, Indonesia \\ E-mail: ${ }^{1}$ chitra@kahuripan.ac.id, ${ }^{2}$ nia@kahuripan.ac.id.com.
}

\begin{abstract}
Salak has the scientific name Salacca zalacca including a low-growing family of palms. This seasonal fruit plant is a type of horticulture that has the potentioal to become an axport commodity in Indonesia. In East Java, especially in Lumajang, Madura and Kediri are areas that produce salak commodities. Morphological identification aims to obtain basic traits so that the appearance or phenotype of each accession can be distinguished quickly and easily, by estimating how much genetic diversity it has. The aims of research to determine the morphological characters and the salak kinship of Lumajang, Kediri and Madura. The result of phylogeny analysis of the Salacca zalacca kinship in East Java show that the results of the kinship analysis of the salak in the Lumajang, Kediri and Madura areas formed 2 large groups or cluster. So it can be concluded that the Salacca zalacca originating from the Lumajang, Kediri and Madura areas still come from the same ancestor. This can be seen from the value of kinship distance, the morphological identificaion equation. In addition, environmental factors can also affect the morphology of plants. Sunlight intensity, N and P nutrients can also affect the difference in leaf color.
\end{abstract}

\section{Key word: morphological, phylogeny, Salacca zalacca, East Java}

\section{PENDAHULUAN}

Salak dinilai sebagai komoditas tanaman hortikultura yang mempunyai peluang potensi di Indonesia. Berdasar pada laporan dari Kementerian Pertanian mengatakan bahwa pada tahun 2018 Indonesia memiliki ekspor untuk komoditas hortikultura yang meningkat sebesar 11,92 persen dengan total nilai yakni lebih dari lima triliun (Santoso, 2019). Salah satu komoditas hortikultura Indonesia adalah buah salak. Indonesia memiliki beberapa varietas buah salak yang unggul antara lain salak pondoh, salak madu, salak gading, salak gula pasir, dan salak sidempuan. Buah salak hidup dan tumbuh di daerah dataran rendah atau dataran tinggi dengan curah hujan rata-rata per tahun 200-400 $\mathrm{mm} /$ bulan. Di Indonesia terdapat banyak sentra daerah penghasil buah salak, seperti Pulau jawa dan Bali, Sulawesi Selatan, Yogyakarta, dan Sumatra Utara (Tim Karya Mandiri, 2010).

Jawa timur merupakan salah satu daerah sebagai komoditas penghasil salak. Berdasarkan laporan data Badan Pusat Statistik (2018), melaporkan bahwa terjadi peningkatan hasil komoditas salak dari 97,05 menjadi 114,10. Daerah penghasil salak di Jawa Timur diantaranya adalah Lumajang, Madura, dan Kediri. Lumajang bahkan terdapat 15 Kecamatan penghasil buah salak yang menjadikan Lumajang identik dengan salak. Masyarakat Madura sering menyebutkan beberapa jenis salak yang ada di daerah madura, seperti salak bukkol, salak penjalin, salak air, Fatimah dan Suryati (2013). Kediri terdapat di daerah Wates Kabupaten Kediri penghasil salak segaran. Namun terkadang, sebutan nama-nama di tiap-tiap daerah belum menentukan bahwa salak-salak tersebut memiliki varietas yang berbeda. 
Penamaan buah salak tersebut berdasar pada bentuk luar dan rasa buahnya saja, sedangkan untuk informasi bagian lainnya belum dipertimbangkan. Kemiripan macammacam salak di tiap daerah seringkali menyebabkan kesulitan untuk membedakannya. Para petani juga belum mengetahui hubungan kekerabatan secara pasti antara jenis salak yang ada di Jawa Timur. Salah satu cara ilmiah yang dapat digunakan untuk mengetahui hubungan kekerabatan atau mencari nenek moyang salak yaitu dengan cara mencandra bentuk luar tanaman salak, mulai dari batang, daun, bunga, sampai buah. Identifikasi morfologi adalah suatu metode yang dapat dengan mudah dilakukan dengan mengamati atau mencandra bagian-bagian tanaman pada sekumpulan tanaman salak yang ada di suatu daerah dan selanjutnya data yang didapatkan digunakan untuk menjabarkan seluk beluk tanaman salak dan asal usul tanaman salak serta untuk perkembangan lanjutan Fatimah dan Suryati (2015).

Penelitian ini memiliki tujuan yaitu untuk mendapatkan informasi mengenai morfologi atau bentuk luar dan filogeni salak dari Lumajang, Madura, dan Kediri sehingga dapat membantu Badan Penelitian dan Pengembangan Jawa Timur dalam mewujudkan tujuan dan sasarannya. Penelitian ini termasuk ke dalam skema penelitian dosen pemula untuk meningkatkan kemampuan dosen dalam mengeksplorasi IPTEK dan publikasi karya ilmiah.

\section{METODE PENELITIAN}

Lokasi penelitian ini adalah tiga daerah di Jawa Timur yakni Lumajang, Madura, dan Kediri. Alat yang dipakai dalam riset ini adalah parang, cutter, roll meter, penggaris, wadah/ember, lup, jangka sorong, haga meter, alat tulis, kamera, buku catatan, dan kertas label. Bahan dalam penelitian ini adalah tanaman salak dari Lumajang, Madura, dan Kediri. Penelitian ini merupakan penelitian deskriptif. Sampel yang diambil memakai metode purposive sampling. Penelitian dari tiga daerah yaitu Lumajang, Madura, dan Kediri. Selanjutnya diamati morfologi atau bentuk luar tanaman salak yang meliputi 1) morfologi batang: bentuk batang, dan arah tumbuh batang; 2) morfologi dari daun dan duri (warna permukaan daun bagian atas, warna permukaan daun bagian bawah,panjang anak daun, lebar anak daun, bentuk ujung anak daun, warna duri yang ada dipelepah daun, warna duri pada buah, bentuk duri, kerapatan duri), 3) morfologi bunga (warna mahkota bunga), serta 4) morfologi buah (meliputi warna kulit buah, jumlah salak pertandan, warna daging buah, tekstur buah, rasa buah, warna biji, jumlah tongkol per tandan).

Analisis Data. Analisis hubungan kekerabatan salak Lumajang, Madura, dan Kediri berdasarkan identifikasi morfologi menggunakan metode numerik. Tahapan yang dilakukan sebagai berikut.

\section{Menentukan OTU (Operasional Taxonomi Units)}

\section{Memilik kriteria}

Kriteria yang dipilih pada tiap jenis atauOTUs, berdasar pada kriteria yang berbeda. Selanjutnya dikonversikan menjadi nilai $1,2,3 \ldots$ dan seterusnya. Kriteria yang tidak ada pada OTUs diberi nilai nol. Selanjutnya dibentuk matriksnya.

\section{Pearson Correlation}

Dilakukan melalui OTUs yang diteliti dengan tujuan menentukan filogeni/kekerabatan antara salak Lumajang, Madura, dan Kediri. dengan menggunakan persamaan:

$$
r_{j k}=\frac{\sum_{j=1}^{n}\left(X_{i j}-\bar{X}_{j}\right)-\left(X_{i \dot{k}}-\bar{X}_{k}\right)}{\sqrt{\sum_{j=1}^{n}\left(X_{i j}-\bar{X}_{j}\right)^{2} \sum_{j=1}^{n}\left(X_{i \bar{k}}-\bar{X}_{k}\right)^{2}}}
$$


Keterangan:

$r j k=$ koefisien korelasi antara STOj dan STOk

$X_{i j}=$ nilai sifat ke i pada $\mathrm{STOj}$

$X j=$ nilai rata-rata dari semua sifat $\mathrm{STO}$

$X i k=$ nilai sifat ke i pada STOj

$X k=$ nilai rata-rata dari semua sifat STOk

$\mathrm{n}=$ jumlah sifat yang dipakai

Langkah berikutnya hasil yang didapatkan disusun menjadi matriks.

\section{Clustering}

Clustering dilakukan dengan metode Average lingkage dan UPGMA. Hasil clustering selanjutnya dipaparkan ke dalam dendogram.

\section{HASIL DAN PEMBAHASAN}

Morfologi atau Bentuk Luar Salak. Salak adalah jenis tanaman hortikultura yang berpotensi menjadi komoditas ekspor di Indonesia. Tanaman salak hidup pada dataran rendah hingga $\pm 800 \mathrm{~m}$ di atas permukaan laut. Tanaman yang berbuah musiman ini merupakan jenis hortikultura yang memerlukan sinar matahari yang cukup tetapi tidak langsung optimalnya sekitar $70 \%$ dengan suhu harian rata-rata $20^{\circ}-30^{\circ}$ C. Derajat keasaaman pada tanaman salak ini yaitu sekitar 4,5 sampai 7,5 Sutoyo dan Suprapto (2010). Tanaman salak memiliki nama ilmiah yatu Salacca edulis atau Salacca zalacca. Buah tropis ini memiliki keunggulan yaitu bernilai gizi cukup tinggi pada setiap $100 \mathrm{gr}$ mengandung $77 \mathrm{kal}, 0,5 \mathrm{gr}$ protein, 20,9gr karbohidrat, $28 \mathrm{mg}$ kalsium, $18 \mathrm{mg}$ fosfor, 4,2mg fe, 0,04mg vitamin B1 dan C 2mg (Pulangkiang, 2017).

Tanaman dari golongan palem rendah ini memiliki batang yang hampir tidak kelihatan. Batang tersebut tertutupi pelepah daun yang tumbuh dengan rapat. Pada bagian tepi daun, batang dan pangkal pelepah memiliki duri tempel khususnya pada permukaan buah salak. Pada usia 1-2 tahun batangnya tumbuh ke samping membentuk anakan atau tunas bunga. Tanaman salak tumbuh hingga ketinggian $\pm 7 \mathrm{~m}$. Buah salak terdiri dari beberapa bagian yaitu kulit, daging buah dan biji. Bagian kulit tersusun atas sisik-sisik yang tersusun rapi dan kulit ari berwarna putih transparan yang menyelimuti daging buah. Warna sisik salak bermacam-macam, ada yang coklat kehitaman, coklat kemerahan, dan coklat keputihan tergantung pada jenisnya (Harahap, 2013).

Jawa Timur khususnya di daerah Lumajang, Madura, dan Kediri merupakan daerah penghasil komoditas salak. Lumajang terdapat 15 kecamatan penghasil buah salak dengan masa panen sepanjang tahun. Panen besar sekitar bulan November-Januari dan bulan Mei-Juni. Panen kecil sekitar bulan Februari-April dan Agustus-Oktober. Mayoritas salak yang ditanam di Lumajang adalah salak pondoh. Madura, khususnya Bangkalan terdapat bermacam-macam jenis salak yang ditanam mulai dari salak mangga, salak aren, salak nangka, salak pandan, salak pepaya, salak penjalin, salak kerbau, salak apel, salak manggis, salak senase, salak bukol, dan salak air. Daerah Kediri khususnya di kecamatan Kunjang dan Segaran, jenis salak yang ditanam petani yaitu salak kunjang hitam, salak kunjang kuning, dalak budeng, dan salak gading (Choiriyah, 2018).

Pengetahuan keanekaragaman tanaman bermanfaat untuk mendukung pemuliaan tanaman. Hal itu dikarenakan informasi-informasi tersebut dapat digunakan untuk menentukan kekerabatan/filogeni antar varietas sebagai dasar seleksi tanaman. Morfologi merupakan ilmu yang memperlajari tentang bentuk luar dari makhluk hidup. Metode morfologi yang dilakukan penelitian ini dengan mengamati bentuk luar yang dapat dilihat oleh mata secara langsung. Identifikasi morfologis memiliki tujuan untuk memperoleh sifat dasar yang dijadikan pedoman atau dasar untuk membedakan 
kenampakan/fenotip dari setiap aksesi, dengan berhipotesis seberapa besar keragaman genetik suatu tanaman. Keberagaman morfologi tanaman salak dapat berdasar pada ciri vegetatif atau generatifnya yang bermanfaat untuk memperoleh paparan dan klasifikasi tanaman salak yang membantu mempermudah dalam menentukan varietas/jenis tanaman salak (Pulakiang, 2017).

Kemiripan ciri kenampakan luar atau morfologi adalah salah satu cara yang dapat dipergunakan untuk mengetahui hubungan kekerabatan antar jenis tanaman. Identifikasi morfologi dapat dilakukan dengan paparan morfologi batang, tinggi tanaman, morfologi daun (warna permukaan bagian daun atas, warna permukaan bagian daun bawah, warna pelepah salak, jumlah anak daun, panjang ibu tangkai daun, panjang anak daun, lebar anak daun, panjang ujung daun, lebar ujung daun, keadaan ujung daun, keadaan ibu tangkai daun), morfologi bunga (susunan bunga, bentuk bunga jantan dan betina, warna mahkota bunga dan benang sari), morfologi buah (warna kulit dan bentuk buah, diameter buah, warna biji, warna kulit buah, jumlah biji, jumlah buah per tandan) serta morfologi duri. Penggunaan keberagaman morfologi menjadi metode yang dapat langsung diterapkan pada populasi salak.

Penelitian ini mengambil beberapa data dari Lumajang yakni ada L1, L2, L3, L4; Data dari Kediri yakni mulai dari K1/KH, K2/KK, K3/Bd, dan K4/GD. Sedangkan untuk Madura yakni daerah Bangkalan karena varietas salak Bangkalan lebih banyak maka data yang didapatkan adalah M1, M2, M3, M4, M5, MA, MP, MK, dan MS. Data yang diperoleh dari penelitian ini yang dilakukan di daerah Lumajang, Kediri, dan Madura adalah sebagai berikut.

Tabel 1 Hasil Data Identifikasi Morfologi Salak Lumajang, Kediri dan Madura.

\begin{tabular}{l|r|r|r|r|r|r|r|r|r|r|r|r|r|r|r|r|r|r|r|r|r|r|}
\hline KARAKTER & BB & ATB & PAD & PBD & PJD & LAD & BUD & PKD & PLD & DPB & DML & BTD & KDR & WKB & JBT & WDB & RSB & TKB & WBJ & WMB & KDB & JTT \\
\hline M1 & 0 & 1 & 1 & 1 & 1 & 2 & 1 & 1 & 3 & 3 & 1 & 1 & 1 & 3 & 0 & 3 & 1 & 1 & 1 & 2 & 1 & 1 \\
\hline M2 & 1 & 1 & 1 & 2 & 0 & 2 & 2 & 1 & 1 & 4 & 0 & 1 & 1 & 4 & 0 & 3 & 2 & 1 & 3 & 2 & 1 & 2 \\
\hline M3 & 0 & 1 & 1 & 2 & 0 & 0 & 2 & 1 & 1 & 1 & 0 & 1 & 1 & 3 & 2 & 2 & 2 & 0 & 3 & 2 & 1 & 2 \\
\hline M4 & 0 & 1 & 1 & 2 & 2 & 1 & 2 & 1 & 1 & 4 & 0 & 1 & 1 & 4 & 2 & 2 & 4 & 1 & 3 & 2 & 1 & 1 \\
\hline M5 & 1 & 1 & 2 & 2 & 3 & 4 & 1 & 1 & 3 & 1 & 1 & 1 & 1 & 4 & 4 & 2 & 2 & 0 & 3 & 1 & 1 & 4 \\
\hline MA & 1 & 1 & 2 & 1 & 0 & 2 & 2 & 1 & 2 & 4 & 0 & 2 & 3 & 3 & 4 & 2 & 5 & 0 & 3 & 3 & 1 & 4 \\
\hline MP & 0 & 1 & 2 & 1 & 2 & 2 & 2 & 1 & 2 & 1 & 0 & 2 & 2 & 3 & 4 & 2 & 5 & 0 & 3 & 3 & 1 & 4 \\
\hline MK & 0 & 1 & 2 & 1 & 1 & 4 & 2 & 1 & 2 & 1 & 0 & 2 & 3 & 3 & 4 & 2 & 2 & 1 & 3 & 1 & 1 & 4 \\
\hline MS & 0 & 1 & 2 & 1 & 0 & 4 & 2 & 1 & 2 & 1 & 0 & 1 & 2 & 3 & 4 & 1 & 5 & 1 & 3 & 1 & 1 & 4 \\
\hline K1/KH & 0 & 1 & 2 & 2 & 3 & 3 & 3 & 1 & 1 & 1 & 0 & 1 & 2 & 4 & 2 & 2 & 2 & 0 & 4 & 1 & 1 & 0 \\
\hline K2/KK & 0 & 1 & 2 & 2 & 2 & 2 & 2 & 1 & 1 & 1 & 0 & 1 & 2 & 3 & 0 & 2 & 4 & 0 & 4 & 4 & 1 & 1 \\
\hline K4/GD & 0 & 1 & 1 & 1 & 4 & 4 & 3 & 1 & 3 & 4 & 0 & 1 & 1 & 4 & 2 & 2 & 3 & 0 & 2 & 4 & 1 & 3 \\
\hline L1 & 0 & 1 & 1 & 1 & 4 & 4 & 1 & 1 & 1 & 1 & 0 & 1 & 1 & 1 & 2 & 2 & 2 & 0 & 2 & 4 & 1 & 4 \\
\hline L2 & 0 & 1 & 1 & 2 & 2 & 1 & 1 & 1 & 1 & 4 & 0 & 1 & 1 & 2 & 4 & 2 & 5 & 0 & 3 & 4 & 1 & 2 \\
\hline L3 & 0 & 1 & 1 & 1 & 2 & 2 & 2 & 1 & 1 & 1 & 1 & 1 & 1 & 3 & 2 & 2 & 4 & 0 & 3 & 1 & 1 & 1 \\
\hline 44 & 0 & 1 & 2 & 2 & 3 & 3 & 1 & 1 & 1 & 1 & 0 & 1 & 1 & 3 & 2 & 2 & 2 & 0 & 3 & 2 & 1 & 2 \\
\hline
\end{tabular}

Keterangan: BB (Bentuk Batang): 0 = Bulat, 1= lonjong; ATB (Arah Tumbuh Batang): 1= tegak; PAD (Warna Permukaan Bagian Atas Daun): 1= Hijau, 2 = Hijau Tua; PBD (Warna Permukaan Bagian Bawah Daun): 1 = Hijau Alur Coklat, $2=$ Hijau Keabuan; PJD (Panjang Anak Daun): $0=$ 38-42, 1 = 43-46, 2 = 47-53, 3=54-62; LAD (Lebar Anak Daun): $0=3-3,7 ; 1=3,8-4,4 ; 2=4,5$ - 5,2; 3 = 5,2 - 5,4; 4: 5,4 - 6,6; BUD (Bentuk Ujung Anak Daun): 1 = Meruncing, $2=$ Runcing, 3 = Tumpul; PKD (Bentuk Pangkal Anak Daun): 1 = rata; PLD (Warna Duri Pada Pelepah): 1 = Coklat, 2 = Hitam Coklat, 3 = Hitam; DPB (Duri Pada Buah): 1 = Coklat, 2 = Coklat Hijau, $3=$ Hijau, 4 = Hitam; DML (Duri Mudah Lepas): 0 = Tidak, 1 = Ya; BTD (Bentuk Duri): 1 = Tipis Lancip Kecil, 2 = Tipis Lancip Besar; KDR (Kerapatan Duri): 1 = Jarang, 2 = Agak Rapat, 3 = Rapat; WKB (Warna Kulit Buah): 1 = Kuning, 2 = Coklat, 3 = Coklat Kehitaman, 4 = Hitam; JBT (Jumlah Buah Per Tandan): $0=20,2=22,4=24$; WDB (Warna Daging Buah): 1 = Putih, $2=$ Putih Kekuningan, 3 = Kuning Kecoklatan; RSB (Rasa Buah): 1 = Kurang Manis, 2 = Manis Sepet, 3 = Asam Sepat, 4 = Manis, 5 = Sangat Manis; TKB (Tekstur Buah): $0=$ Tidak Masir, $1=$ Masir; WJB (Warna Biji): 1 = Coklat Kekuningan, 2 = Coklat, 3 = Coklat Tua, 4 = Coklat 
Kehitaman; WMB (Warna Mahkota Bunga): $1=$ Merah Muda, $2=$ Merah, $3=$ Merah Kekuningan, 4 = Merah Tua; KDB (Kedudukan Bunga): $1=$ Diketiak Pelepah; JTT (Jumlah Tongkol / Tandan): $0=2,1=3,2=4,3=5,4=6$.

Pada penelitian ini dilakukan identifikasi morfologi dari pohon salak yang meliputi: bentuk batang, arah tumbuh batang, warna permukaan bagian atas daun, warna permukaan bagian bawah daun, panjang dan lebar anak daun, bentuk ujung dan pangkal anak daun, warna duri pada pelepah daun dan buah, jenis duri mudah lepas atau tidak, bentuk duri, kerapatan duri, warna kulit buah, jumlah buah per tandan, warna daging buah, rasa buah, tekstur buah, warna biji buah, warna mahkota bunga, kedudukan bunga serta jumlah tongkol per tandan. Sampel penelitian yang digunakan adalah salak di daerah Lumajang dengan kode L1, L2,L3, dan L4. Ada pula salah di daerah Kediri dengan kode K1KH, K2KK, K3BD, dan K4GD. Berikutnya ada beberapa salak dari Madura yakni M1, M2, M3, M4, M5, MA, MP, MK, dan MS. Sehingga total terdapat 17 sampel yang digunakan dalam penelitian ini. Selanjutnya setelah diperoleh data hasil identifikasi morfologi tersebut, dilakukan analisis untuk mendapatkan hubungan kekerabatan dari setiap jenis salak dari beberapa daerah di Jawa Timur tersebut.

Analisis data dalam penelitian ini bertujuan untuk memaparkan hubungan kekerabatan salak Lumajang, Kediri, dan Madura. Berdasarkan data yang telah diperoleh dari hasil identifikasi morfologi salak selanjutnya dilakukan langkah-langkah yakni penentuan operasional taxonomi units dan pemilihan karakter untuk dijadikan indikator dalam mengidentifikasi kekerabatannya (Pearson, 2020). Langkah berikutnya setelah data berhasil dianalisis akan ditampilkan nilai kemiripan dari masing-masing sampel penelitian yang diambil seperti ditunjukkan pada gambar sebagai berikut Gambar 1.

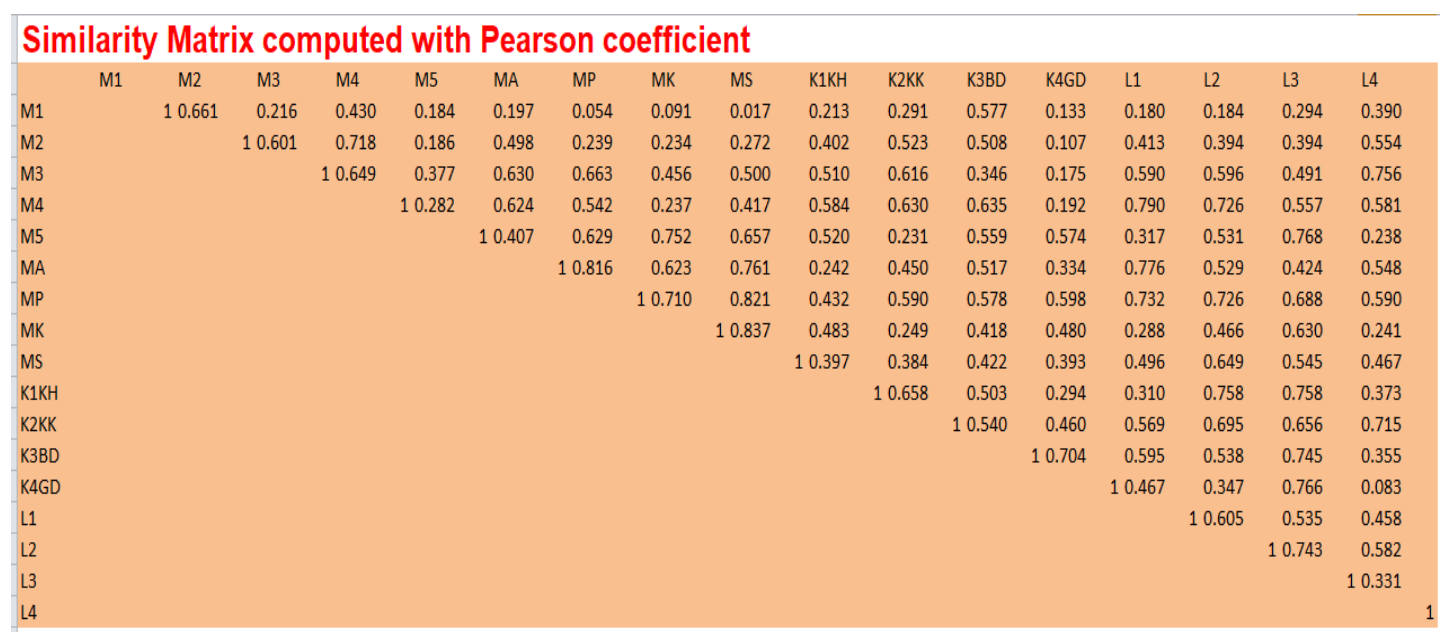

Gambar 1 Hasil Analisis Identifikasi Salak Di Jawa Timur

Berikutnya akan ditampilkan pula data tabel untuk melihat jarak kekerabatan dari masingmasing sampel riset yang dilakukan baik dari Lumajang, Kediri maupun dari Madura. Dan data tersebut terlihat pada Gambar 2 berikut ini. 
p-ISSN: 1978-5259 e-ISSN: 2527-3345

Copyright@UNISBA Blitar, http://ejournal.unisbablitar.ac.id/index.php/viabel

Chitra Dewi Yulia Christie \& Nia Agus Lestari, 2020. Identifikasi Morfologi Dan Kekerabatan

Salak Di Jawa Timur. Journal Viabel Pertanian. (2020), 14(2)26-33

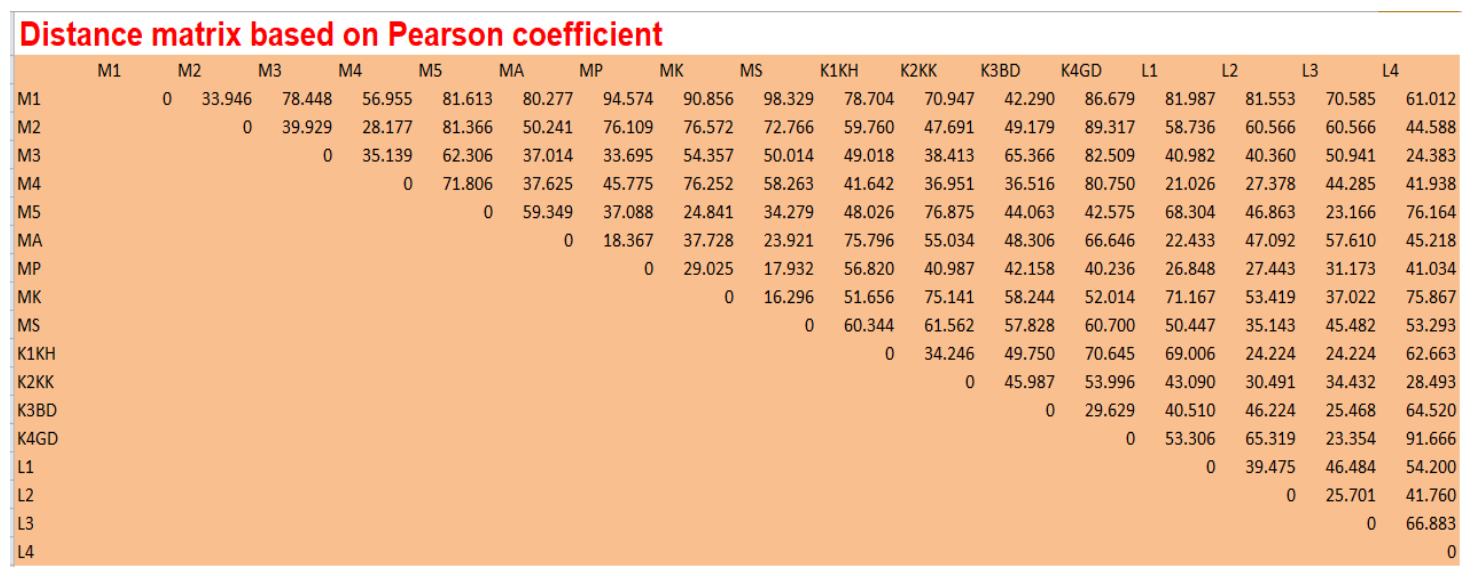

Gambar 2 Jarak Kekerabatan berdasarkan Pearson

Langkah selanjutnya dalam riset ini adalah membuat dendogram atau pohon filogenetik untuk melihat kekerabatan antara Salak di Lumajang, Kediri maupun di Madura. Melalui pohon filogenetik atau dendogram tersebut akan ditampilkan hubungan kekerabatan dari setiap sampel salak yang digunakan sehingga dapat disimpulkan hubungan kekerabatannya. Untuk pembuatan dari pohon filogenetik atau dendogram tersebut dilakukan dengan metode UPGMA Puigbo et al, (2002). Sehingga akan ditunjukkan melalui gambar 3 dibawah ini.

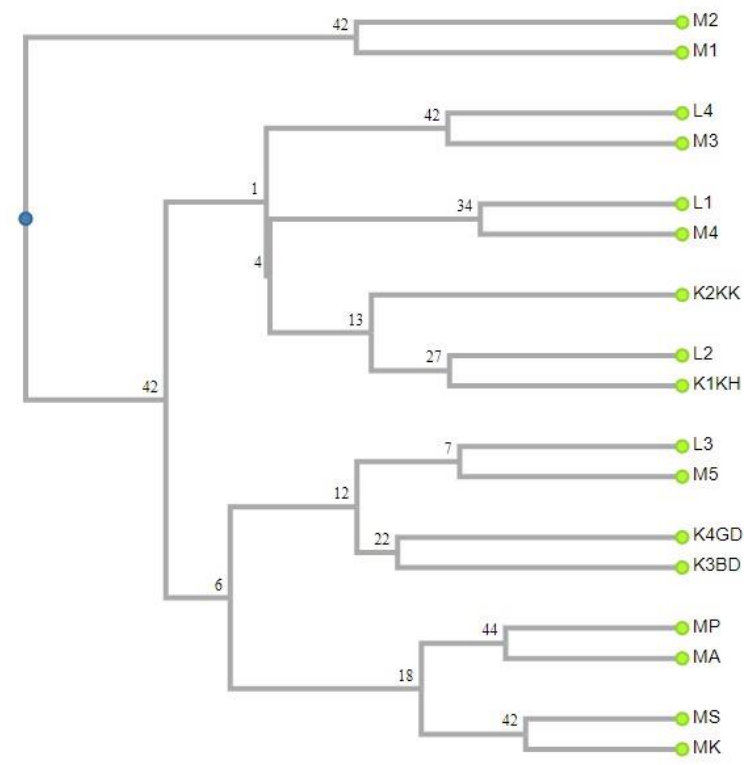

Gambar 3 Pohon Filogeni Hasil Kekerabatan Salak Di Jawa Timur

Pada hasil analisis filogeni kekerabatan salak di Jawa Timur menunjukkan bahwa hasil analisis kekerabatan salak di daerah Lumajang, Kediri, dan Madura terbentuk 2 kelompok atau cluster besar yakni cluster A yang terdiri dari M1 dan M2, dan juga cluster B. Pada cluster B masih terbagi lagi menjadi 2 kelompok yakni B1 yang terdiri dari L4, M3, L1, M4, K2KK, L2, dan K1KH. Sedangkan untuk cluster B2 terdiri dari L3, M5, K4GD, K3BD, MP, MA, MS, dan MK. 
p-ISSN: 1978-5259 e-ISSN: 2527-3345

Copyright@UNISBA Blitar, http://ejournal.unisbablitar.ac.id/index.php/viabel

Chitra Dewi Yulia Christie \& Nia Agus Lestari, 2020. Identifikasi Morfologi Dan Kekerabatan Salak Di Jawa Timur. Journal Viabel Pertanian. (2020), 14(2)26-33

Tabel 2 Pengelompokan Hasil Analisis Kekerabatan Salak Jawa Timur

\begin{tabular}{lll}
\hline Cluster A & Cluster B1 & Cluster B2 \\
\hline M1 & L4 & L3 \\
\hline M2 & M3 & M5 \\
\hline & L1 & K4GD \\
\hline & M4 & K3BD \\
\hline & K2KK & MP \\
\hline & L2 & MA \\
\hline & K1KH & MS \\
\hline
\end{tabular}

Dari hasil analisis kekerabatan atau filogeni terlihat bahwa mayoritas salak daerah Lumajang, Kediri, dan Madura masih terdapat dalam satu kelompok besar sehingga dapat disimpulkan bahwa salak yang berasal dari daerah Lumajang, Kediri, dan Madura masih berasal dari nenek moyang yang sama. Hal tersebut dapat terlihat dari nilai jarak kekerabatan, persamaan identifikasi morfologinya. Selain itu faktor lingkungan juga dapat mempengaruhi morfologi dari tanaman. Intensitas cahaya matahari, unsur hara $\mathrm{N}$ dan $\mathrm{P}$ juga dinilai mempengaruhi dari perbedaan warna daun tanaman Ariestin et al, (2015). Hasil penelitian ini mengatakan bahwa pengelompokan salak di Jawa Timur tidak berkelompok berdasarkan daerah asal masing-masing. Hal tersebut sejalan dengan pendapat dari Fatimah yang menyatakan pada lingkungan yang berbeda dapat terjadi adanya penghanyutan genetik dan seleksi alam yang menyebabkan keanekaragaman genetik yang lebih besar daripada jarak geografi (Fatimah, 2013). Jika pada lingkungan tumbuh tanaman berbeda maka akan mempengaruhi keanekaragaman dari genetiknya. Semakin banyak persamaan karakter morfologi maka akan semakin adanya kedekatan hubungan kekerabatan atau filogenetiknya. Sebaliknya semakin kecil kemiripan karakter penampakan luar atau morfologi maka akan semakin jauh hubungan kekerabatannya (Miswarti, 2017).

\section{KESIMPULAN}

Kesimpulan yang dapat diperoleh dari hasil penelitian Identifikasi Morfologi dan Kekerabatan Salak Di Jawa Timur ini bahwa morfologi dari salak daerah Lumajang, Kediri, dan Bangkalan memiliki ciri-ciri tersendiri dan setiap daerah memiliki ciri-ciri mulai dari morfologi batang, daun, buah yang bermacam-macam. Dan hasil kekerabatan dari salak daerah Lumajang, Kediri, dan Bangkalan ini adalah terdapat dua kelompok besar salah satunya berisi salak dari Madura, dan kelompok satu lagi merupakan campuran dari salak Kediri, Lumajang, dan Madura. Sehingga dapat disimpulkan bahwa dalam penelitian ini salak dari daerah Lumajang, Kediri, dan Madura memiliki nenek moyang yang sama. 


\section{DAFTAR PUSTAKA}

Ariestin, Yuliamita K, Sumeru, A. 2015. Keragaman Jenis Salak Bangkalan \{Salacca Zalacca (Gaertner) Voss\} Menggunakan Penanda Morfologi Dan Analisis Isozim. Malang : Jurnal Produksi Tanaman, 2015, Vol. 3 Nomor 1.

Badan Pusat Statistik. 2018. Indeks Berantai Luas Panen Sayuran dan Buah-buahan. Tahunan di Jawa Timur Tahun 2009-2017. https://jatim.bps.go.id/statictable/2018/11/06/1373/indeks-berantai-luas-panen sayuran-dan-buah-buahan-tahunan-di-jawa-timur-2009-2017.html.Imam, Santoso. 2019. Warta Pertanian Menuju Kedaulatan Pangan. Kementerian Pertanian. Jakarta.

Choiriyah, Novy N. 2018. Karakterisasi Morfologi Salacca zalacca (Gaertner) Voss Kediri. s.1. : Jurnal Simki-Techsain, 2018, Vol. Volume 02. ISSN : 2599-3011.

Fatimah S. 2013. Analisis Morfologi dan Hubungan Kekerabatan Sebelas Jenis Tanaman Salak (Salacca zalacca (Gertner) Voss) Bangkalan. s.l. : Agriovor, 2013, Vol. 6 Nomor 1.

Fatimah dan Suryawati. 2013. Analisis Morfologi dan Hubungan Kekerabatan Sebelas Jenis Tanaman Salak (Salacca zalacca (Gertner))Voss Bangkalan. s.l. : Agrovigor, 2013, Vol. 6. 19795777.

Fatimah dan Suryawati. 2015. Uji Kekerabatan Antara Salak Jantan dan Salak Betina (Salacca zalacca (Gertner)) Voss Bangkalan. s.l. : Agriovor, 2015, Vol. 8. 1979 5777.

Harahap H M Y, Bayu E S, Siregar L A M. 2013. Identifikasi Karakter Morfologis Salak Sumatera Utara (Salacca sumatrana Becc) di Beberapa Daerah Kabupaten Tapanuli Selatan. s.l. : Jurnal Online Agroekoteknologi, 2013, Vol. Volume 1. ISSN: 2337-6597.

Miswarti. Analisis Keragaman Plasma Nutfah Durian Di Provinsi Bengkulu Berdasarkan Karakter Morfologi. Bengkulu : Bul.Plasma Nutfah, 2017, Vol. 23 Nomor 1.

Pearson. 2020. Pearson correlation coefficient. Wikipedia. [Online] Agustus 2020. https://en.wikipedia.org/wiki/Pearson_correlation_coefficient.

Puigbo, Vallve S G, Pere. 2002. DendroUPGMA: A dendrogram construction utility. DendroUPGMA: A dendrogram construction utility. [Online] 2002. http://genomes.urv.cat/UPGMA/.

Pulakiang, Andrew R. 2017. Beberapa Karakter Morfologis Tanaman Salak (Salacca zalacca (Gertner) Voss di Kampung Bawoleu Kecamatan Tagulandang Utara, Kabupaten Kepualuan Siau Tahulandang Biato). Manado : Jurnal Eugenia , 2017, Vol. Volume 23.

Sutoyo, dan Suprapto. 2010. Budidaya Tanaman Salak. Balai Pengkajian Teknologi Pertanian. Jawa Tengah.

Tim Karya Mandiri. 2010. Pedoman Budidaya Buah Salak. CV Nuansa Aulia. Bandung. 